\title{
Phytochemical Screening, Spectroscopic Examination and Antimicrobial Evaluation of PHE (Poly Herbal Extract) of Selected Indian Medicinal Herbs
}

\author{
P. Manorama, Gangadhara Angajala, Geetha Das
}

\begin{abstract}
Methanolic extract of important medicinal herbal plants like Marsilea-quadrifolia (whole plant), Trigonella-foenum-graecum (whole plant), Leaves of Mangifera-indica, Seeds of Eugenia-jambolana, Flowers of Cassia-auriculata, Flower of Musa- paradisiaca, Leaves of Aegle-marmelos and equal ratio of the mixture of the seven plants (Poly Herbal Extract - PHE) was prepared. The phytochemical screening for all the individual plants and PHE have been studied by using $U V, I R, T L C$ and $A A S$. The results obtained from spectroscopic analysis indicated the presence of alkaloid, carbohydrates, protein, phenols, tannin, saponin, triterpenoids, glycosides, phytosterols, gums and mucilage. The results of TLC for seven plants and PHE showed the Rf factor in confirmation with phytochemical and spectrometric analysis. The atomic absorption studies reflected the presence of copper, iron, magnesium and zinc metals in PHE. Antimicrobial studies for all the individual plants and $P H E$ were carried towards gram positive bacteria Bacillus subtilis and gram negative bacteria Pseudomonas aeruginosa, Escherichia coli respectively. The in vitro antimicrobial studies also revealed that PHE showed better activity against $E$. coli which is comparable with the standard ciprofloxacin.
\end{abstract}

Keywords: Medicinal plants, Poly Herbal Extract (PHE), Spectroscopy, Antimicrobial.

\section{INTRODUCTION}

Plants have been part of our lives since the beginning of time and during the past decade traditional system has gained importance in the field of medicine. According to the world health organization it is estimated that nearly $80 \%$ of the world population either directly or indirectly using herbal medicine for their primary health [1-3]. Plants play a vital role in humans as they possess several active constituents which are the precursors for the synthesis of many drugs [4-5]. Plant is a biosynthetic laboratory not only for chemical compounds but also multitude of compounds like glycosides and alkaloids

Revised Manuscript Received on December 15, 2019.

* Correspondence Author

Gangadhara Angajala*, Chemistry, Kalasalingam Academy of Research and Education, Krishnankoil, Virudhunagar, India.

Email: gangadharaangajala@gmail.com

P.Mamorama, Chemistgry, Kalasalingam Academy of Research and Education, Krishnankoil, Virudhunagar, India.

Email: manorama.p.jeyarajam@gmail.com

Geetha Das, Chemistry, Kalasalingam Academy of Research and Education, Krishnankoil, Virudhunagar, India.

Email: geethachem2015@gmail.com
[6]. The use of herbal medicine is increasing day by day mainly because of its safety, efficacy and quality. Before the onset of synthetic era, man was completely dependent on medicinal herbs for the treatment of various diseases. Many of the drugs used today are of herbal origin, indeed nearly $25 \%$ of the prescription drugs contain at least one active compound derived from the plant origin [7-8].

Pharmacological studies have accepted the value of medicinal plants as potential source of bioactive compounds. Hence plants are good sources for new safe, biodegradable and renewable drugs. The screening of the plant extracts has been of great interest to scientists in the search for new drugs for effective treatment of several diseases. Several studies have revealed that parts of herbal plants including seeds, stem, leaves, roots and flower contribute to their antidiabetic, antibacterial, antioxidant, antifungal and anti-carcinogenic and other medicinal activities [9]. Now a day the number of cases recorded for multidrug resistant bacterial infections is increasing at an alarming rate all over the world. Disease causing microbes that have become resistant to drug therapy are causing severe threat to public health. Malaria, tuberculosis, gonorrhea and childhood ear infections are just a few diseases that have become difficult to treat with antibiotic drugs that are currently available in the market. So there is a still need for the new classes of antimicrobial agents, possibly acting through the mechanisms which are distinct from those of well-known classes of antimicrobial agents to which many clinically relevant pathogens may be now resistant [10].

The present study focusses on the aspects of individual methanolic herbal extract screening to assess the phyto chemical constituents for antimicrobial activity. The species used are Marsilea-quadrifolia (Family: Marsileaceae), Trigonella-foenum-graecum (Family: Fabaceae), Mangifera -indica (Family: Anacardiaceae), Eugenia-jambolana (Family: Myrtaceae), Cassia-auriculata (Family: Leguminosae), Musa-paradisiaca (Family: Musaceae), Aegle-marmelos (Family: Rutaceae). The non-nutritive phytochemicals in plants have protective effect against various diseases and disorders. Also, the beneficial medicinal effects of plant extract materials have also resulted from the combination of secondary products present in the plants.

\section{Published By:}

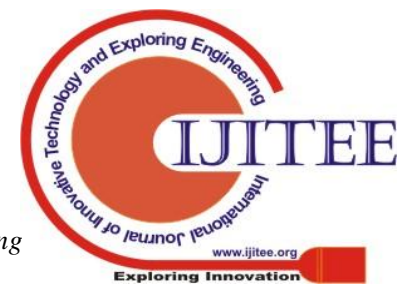


Phytochemical Screening, Spectroscopic Examination and Antimicrobial Evaluation of PHE (Poly Herbal Extract) of Selected Indian Medicinal Herbs

\section{MATERIALS AND METHODS}

\section{A. Collection of Plant Material}

Seven folk medicinal plants viz:, Marsilea-quadrifolia (whole Plant), Trigonella-foenum-graecum (Whole Plant), Mangifera-indica (Leaves), Eugenia-jambolana (Seeds), Cassia-auriculata (Flowers), Musa-paradisiaca (Flower), Aegle-marmelos (Leaves ) were collected from Madurai district. The selected plants were authenticated by Dr. M. Shanthi, HoD, Department of Botany, S.F.R College, Sivakasi, Tamilnadu, India. The plant materials were collected washed thoroughly with the tap water, shade dried, homogenized to fine powder and stored in an air tight bottle.

\section{B. Preparation of Solvent Extract}

Preparation of the extract of various parts of the seven herbal plant powder was done using methanol as a solvent medium. The shade dried coarse herbal powder $100 \mathrm{~g}$ packed well in Soxhlet apparatus and was subjected to continuous hot extraction with methanol separately until the completion of the extraction. The extract was filtered while hot and the resultant extract was distilled in vacuum under reduced pressure in order to remove the solvent completely. It was dried and kept in a desiccator till experimentation. Obtained extract was weighed, practical yield was calculated in terms of air dried powdered crude material as given in Table-I, Fig.1.

\section{Phytochemical Screening}

Phytochemical examinations were carried out for all the extracts as per the standard methods [11].

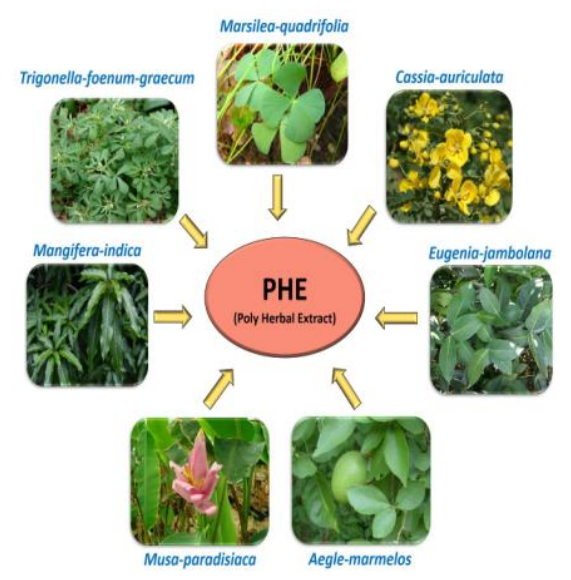

Fig.1. Preparation of PHE (poly herbal extract) from selected medicinal herbs

TABLE 1: Plants used for the preparation of PHE (Poly Herbal Extract)

\begin{tabular}{lllll}
\hline S.No & Name of the Plant & Parts used & $\begin{array}{l}\text { Practical } \\
\text { yield in } \\
\text { gms }\end{array}$ & T \\
\hline 1 & Marsila -quadrifolia & Whole plant & 1.75 & W \\
2 & Trigonella -foenum -graecum & Whole plant & 1.34 & Th \\
3 & Cassia-auriculata & Flowers & 1.55 & 1 \\
4 & Mangifera-indica & Leaves & 2.02 & 7 \\
5 & Musa-paradisiaca & Flower & 0.75 & \\
6 & Eugenia-jambolana & Seeds & 1.32 & \\
7 & Aegle -marmelos & Leaves & 1.45 & \\
8 & Poly Herbal Powder & All the above (Equal & 2.28 \\
& & ratio) & & \\
\hline
\end{tabular}

UV- visible spectra were recorded on UV-VIS spectrophotometer SHIMADZU Pharma Spec UV-1700 model at room temperature. Scanning of the methanolic solution of all the eight raw sample solution were performed at the wavelength range of $200-800 \mathrm{~nm}$.

\section{- Thin layer chromatography}

Each solvent extract was subjected to thin layer chromatography (TLC) as per conventional one dimensional ascending method using silica gel 60F254, 7 x $6 \mathrm{~cm}$ (Merck) were cut with ordinary house hold scissors. Plate markings were made with soft pencil. Glass capillaries were used to spot the sample for TLC by using capillary at distance of $1 \mathrm{~cm}$ at 5 tracks. Retention factor (Rf) values for the different spots were found out. Solvent system of hexane, ethyl acetate, acetic acid, chloroform, acetone, alcohol with varied proportion was used for all the eight herbal samples.

\section{- Fourier Transform Infra-Red Spectroscopy}

The IR Spectrum was recorded using the potassium-bromide pellets on Fourier Transform Infra-red spectrometer SHIMADZU FTIR-8400 model. IR data of all the eight herbal samples were compared for the presence of various types of bonds, groups and functional groups through IR chart given in supplementary data.

\section{- Atomic Absorption Spectroscopy}

The Atomic absorption spectrum was recorded in Atomic absorption spectrophotometer SHIMADZU AA-6300 model. $1 \mathrm{M}$ methanol solution of PHE was used to detect the concentration of the elements copper, magnesium, zinc and iron.

\section{E.Antimicrobial Evaluation}

The antimicrobial properties of the extracts towards Bacillus subtilis, Escherichia coli and Pseudomonas aeruginosa were determined in vitro using the agar diffusion method. The tested samples were dissolved in DMSO $(10 \mathrm{mg} / \mathrm{ml})$ Mueller-Hinton agar medium containing Beef extract - $30 \mathrm{~g}$; Casein hydrolysate - 17.5 gm; Soluble Starch - 1.5 gm; Agar 20 gm or $2 \%$; Sodium Hydroxide - 5 gm; Purified water $1000 \mathrm{ml}$; Final $\mathrm{pH}$ at $25{ }^{\circ} \mathrm{C}-7.4 \pm 0.2$ was used for the preparation of inoculum.

\section{Method}

The beef extract casein hydrolysate, soluble starch and agar were taken in the above proportions and dissolved up to 1000 $\mathrm{mL}$ of distilled water. The constituents were heated gently at $100{ }^{\circ} \mathrm{C}$ with agitation. The $\mathrm{pH}$ of the medium was adjusted to 7.4 using sodium hydroxide.$$
\text { \&ciences Publication }
$$ 
Then it was transferred to boiling tubes in hot condition and sealed with non-absorbent cotton and sterilized by autoclaving at $121{ }^{\circ} \mathrm{C}$ (15 lbs pressure) for $15 \mathrm{~min}$. Then poured aseptically into sterile petridishes.

\section{- Working conditions}

The entire work was done on horizontal laminar air flow cabinet so as to provide aseptic conditions. Before commencement of the work, air sampling was carried out using a sterile Muller Hinton agar plate and exposing it to the environment inside the cabinet. On incubation it was checked for the growth of microorganism and absence of growth conformed the aseptic working conditions.

\section{- Inoculation of micro organism}

The sterilized Muller Hinton Agar media was heated on a water bath to melt the media. When the media was lukewarm, the organism were inoculated separately and poured aseptically into sterile Petri dishes and allowed to solidify. Cups of $8 \mathrm{~mm}$ diameter were cut using sterile glass borer. To the cups, the standard drug ciprofloxacin $(50 \mu \mathrm{g} /$ well $)$ and plant extracts $(1000 \mu \mathrm{g} /$ well $)$ was poured separately and tween $80(1 \%)$ was taken as blank. The petri dishes were kept in the refrigerator for one hour to facilitate uniform diffusion of the drug and later kept in the incubator for a period of $24 \mathrm{~h}$ at $37{ }^{\circ} \mathrm{C}$. Observations were made for the zone of inhibition around the extracts and compared with that of standard.

\section{RESULTS AND DISCUSSION}

\section{A. Phytochemical Screening}

The methanolic extract of Marsilea-quadrifolia (whole Plant), Trigonella-foenum-graecum (whole Plant), Cassia-auriculata (flowers), Mangifera-indica (leaves), Musa-paradisiaca (flower), Eugenia-jambolana (seeds) Aegle marmelos (leaves) and Poly-Herbal-Extract (PHE) were subjected to qualitative phytochemical screening for the detection of phyto constituents like alkaloids, proteins and amino acids, carbohydrates, flavanoids, triterpenoids, phenols, phytosterols, tannins, glycosides, saponins, gums and mucilages. The test results are shown in Table-II. Phytochemical constituents and several other aromatic compounds are secondary metabolites of plants that serve as defense mechanism against many organisms. Proteins, carbohydrates and flavones are present in all the eight herbal samples. Proteins contribute to the structure and functions of the living cell. They are present as independent units as well as in combination with lipids, nucleic acids, carbohydrates and many other compounds. Methanolic extract of PHE contain all the phytochemical constituents. Terpenoids are present in sample 3 and PHE. Terpenoids furnish to analgesic and anti-inflammatory activities. Saponins are present in samples 3, 5, 7 and 8. Terpenoids and saponins function as regulators of mechanism and play a protective role as an antioxidant. They are able to form a hydro-peroxide intermediate, thus preventing cell damages by free radicals. Flavanoids and phenolic compounds in plants function as primary oxidants or free radical scavengers. Flavanoids have been found to possess many useful properties including anti-inflammatory, enzyme inhibition, antimicrobial, antiallergic, antioxidant and antitumour activity. Flavanoids and alkaloids reported to possess hypoglycemic activities [12]. Alkaloids are present in samples 2, 4, 5, 7 and 8 . Alkaloids possess nitrogen atoms that have lone pair of electrons that can be used to form co-ordinate covalent bonds with metal ions. Alkaloids are antibacterial in activity due to toxic property. These compounds are able to reduce $\mathrm{H} 2 \mathrm{O} 2$ induced oxidation by donating hydrogen atoms. Tannins and phenolic compounds are present in samples 1, 2, 4, 5 and 7. Tannin accounts for the astringency of the powder. Phyto-sterols are present in samples $1,2,3,4,7$ and 8 . The presence of bio-active compounds indicate the medicinal value of the herbal plants. These phyto chemical compounds have retarding effect to the conversion of starch into sugar.

\section{B. UV-Visible Studies}

UV Spectrum of all the eight herbal samples are displayed in Fig 2A-2N. UV Spectra of phenolic acids showed the absorption band between 200-290 nm range and flavonoid glycones reflected gradual rise in the absorption band between 240-550 $\mathrm{nm}$ range as shown in Fig.2 [13].

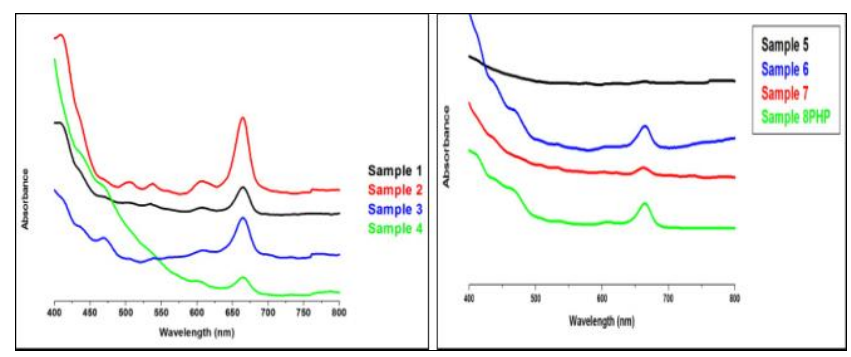

Fig.2. UV-Visible spectrum analysis of eight herbal extracts

The samples 1, 2, 4 and 6 showed seven peaks and PHE showed 6 peaks in the UV-Vis spectrophotometric analysis. Sample 3 located 5 peaks whereas samples 5 and 7 showed each with 3 peaks. Maximum absorption peak noted around $664 \mathrm{~nm}$ located the presence of chlorophyll 'a'. The absorption peak located at $532 \mathrm{~nm}$ for samples $(1,2,4,6,7$ and 8) indicated the presence of anthocyanin. Carotenoids have broad absorption range between $400 \mathrm{~nm}$ to $500 \mathrm{~nm}$ as shown for samples 1, 2, and 4 with absorption wavelength at 406.5 $\mathrm{nm}, 409.5 \mathrm{~nm}$ and $468 \mathrm{~nm}$ respectively. The absorption peak located at $468 \mathrm{~nm}$ for sample 4 assigned the presence of chlorophyll 'b'. Cholorophyll 'a' fluoresces at $665 \mathrm{~nm}, 733 \mathrm{~nm}$ and above.

\section{Thin Layer Chromatographic Studies}

The TLC profiling of the leaves, flowers, seeds and whole plant extracts of all the eight herbal plants give an impressive result directing towards the presence of number of phytochemicals [14] as given in Table-III. The Rf Values of the phytochemicals provide a clue in understanding of their polarity and helps in selection of appropriate solvent system for separation of pure compounds by column chromatography.

\section{Published By:}


Samples 1, 4 and 6 each showing three spots around 0.2, 0.6, $0.7,0.5$ suggests the presence of amino acid, alkaloid and flavanoid. Sample 3 gives 3 spots around 0.2, 0.7, 0.8 confirming the presence of amino acid, flavanoid and terpenoid. Sample 7 represents 3 spots around $0.3,0.5$ and 0.8 in accordance with the phytochemicals flavanoid, alkaloid and phytosterols whereas sample 8 exhibits five spots around $0.1,0.4,0.5,0.6,0.7$ and 0.9 corresponding to amino acids, flavanoid, alkaloid, saponin and terpenoids.

\section{Fourier Transform Infra-Red Spectroscopy}

IR data for all the eight herbal samples displayed several absorption peaks ranging from $3560 \mathrm{~cm}-1$ to $580 \mathrm{~cm}-1$ as shown in Fig.3. These peaks from its analysis through IR-chart confirmed the presence of various bonds and functional groups. Infra-Red studies of all the eight herbal samples indicate the presence of benzene ring, peroxide group, aldehyde group, amino group, secondary amino group, $\mathrm{C}=\mathrm{O}$ group, $-\mathrm{COOH}$ group, double bonds, $-\mathrm{Ar}$ group, halogen alkyl groups, aryl primary amine and ether groups.

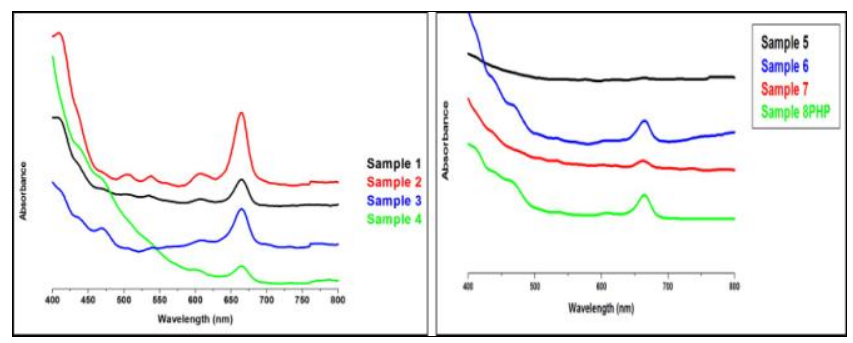

Fig.3. FT-IR analysis of eight herbal extracts

\section{E.Atomic Absorption Spectroscopy}

The atomic absorption studies for PHE showed the presence of Magnesium, Iron, Zinc and copper as indicated by the values $4.9632 \mathrm{ppm}, 0.4658 \mathrm{ppm}, 0.223 \mathrm{ppm}$ and $0.1284 \mathrm{ppm}$ respectively. Magnesium is present in the magnesium porphyrin ring of the chlorophyll 'a', ' $b$ ' and ' $c$ ' in the chloroplast of green plants. Copper and iron present in the chloroplast are essential for Haemoglobin formation. The presence of magnesium and zinc in plants are good sources of anti-diabetic activity [15-16].

\section{F. Antimicrobial Evaluation}

In vitro antimicrobial activity of methanol extracts of the seven medicinal plants and PHE, against gram +ve and gram -ve bacteria by Agar Diffusion Method were presented in Table-IV and Fig.4. The results highlighted varying degree of inhibition against the tested micro-organism. All the eight herbal samples were reported to exhibit the moderate antibacterial activity against Pseudomonas aeruginosa and Bacillus subtilis and good activity against E.coli when compared to the standard ciprofloxacin. Elevated activity of PHE to both gram -ve and gram +ve bacterial strains may be attributed due to the presence of secondary metabolites in abundance.

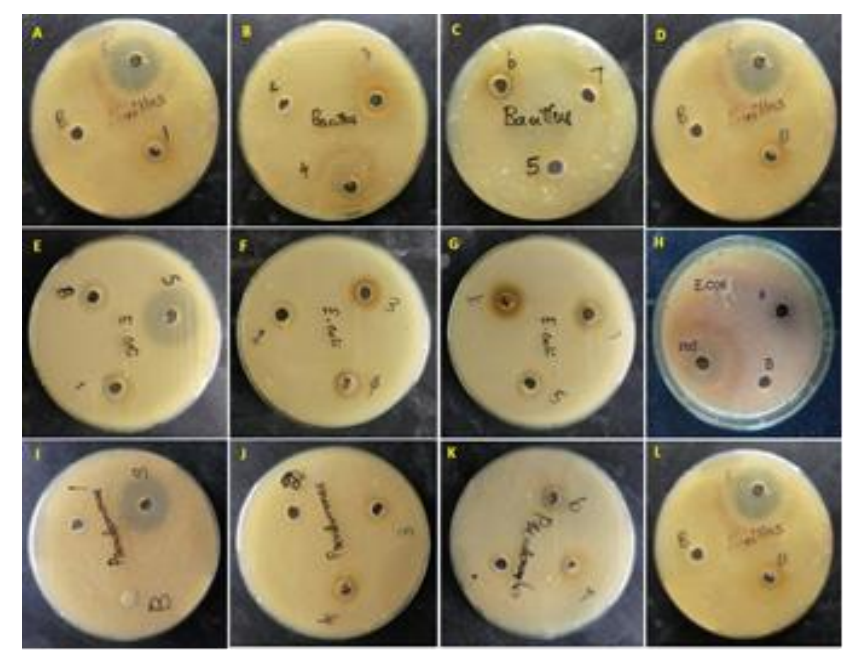

Fig.4. Antimicrobial activity of the various extracts [A-D] Effect of Herbal extracts on Bacillus subtilis [E-H] Effect of Herbal extracts on Escherichia coli [I-L] Effect of Herbal extracts on Pseudomonas aeruginosa.

Table- II: Antimicrobial analysis of herbal extracts

\begin{tabular}{cccc}
\hline \multirow{2}{*}{ Sample } & \multicolumn{3}{c}{ Zone of the Inhibition in m.m. \pm S.E } \\
\cline { 2 - 4 } & $\begin{array}{c}\text { Bacillus } \\
\text { subtilis }\end{array}$ & $\begin{array}{c}\text { Pseudomonas } \\
\text { aeruginosa }\end{array}$ & E.coli \\
\hline 1 & $06 \pm 0.70$ & $03 \pm 0.40$ & $04 \pm 0.45$ \\
2 & 0 & $02 \pm 0.42$ & $03 \pm 0.38$ \\
3 & $05 \pm 0.48$ & $03 \pm 0.40$ & $05 \pm 0.36$ \\
4 & $03 \pm 0.37$ & $05 \pm 0.40$ & $04 \pm 0.43$ \\
5 & $02 \pm 0.26$ & $02 \pm 0.18$ & $05 \pm 0.39$ \\
6 & $03 \pm 0.28$ & $03 \pm 0.36$ & $07 \pm 0.76$ \\
7 & 0 & $03 \pm 0.38$ & $08+0.72$ \\
PHE & $06 \pm 0.35$ & $07 \pm 0.44$ & $10 \pm 0.46$ \\
Std $^{\text {a }}$ & $15 \pm 1.50$ & $10 \pm 0.75$ & $12 \pm 0.80$ \\
\hline
\end{tabular}

${ }^{\mathrm{a}}$ Ciprofloxacin 
Table- III : Preliminary phytochemical studies of herbal extracts

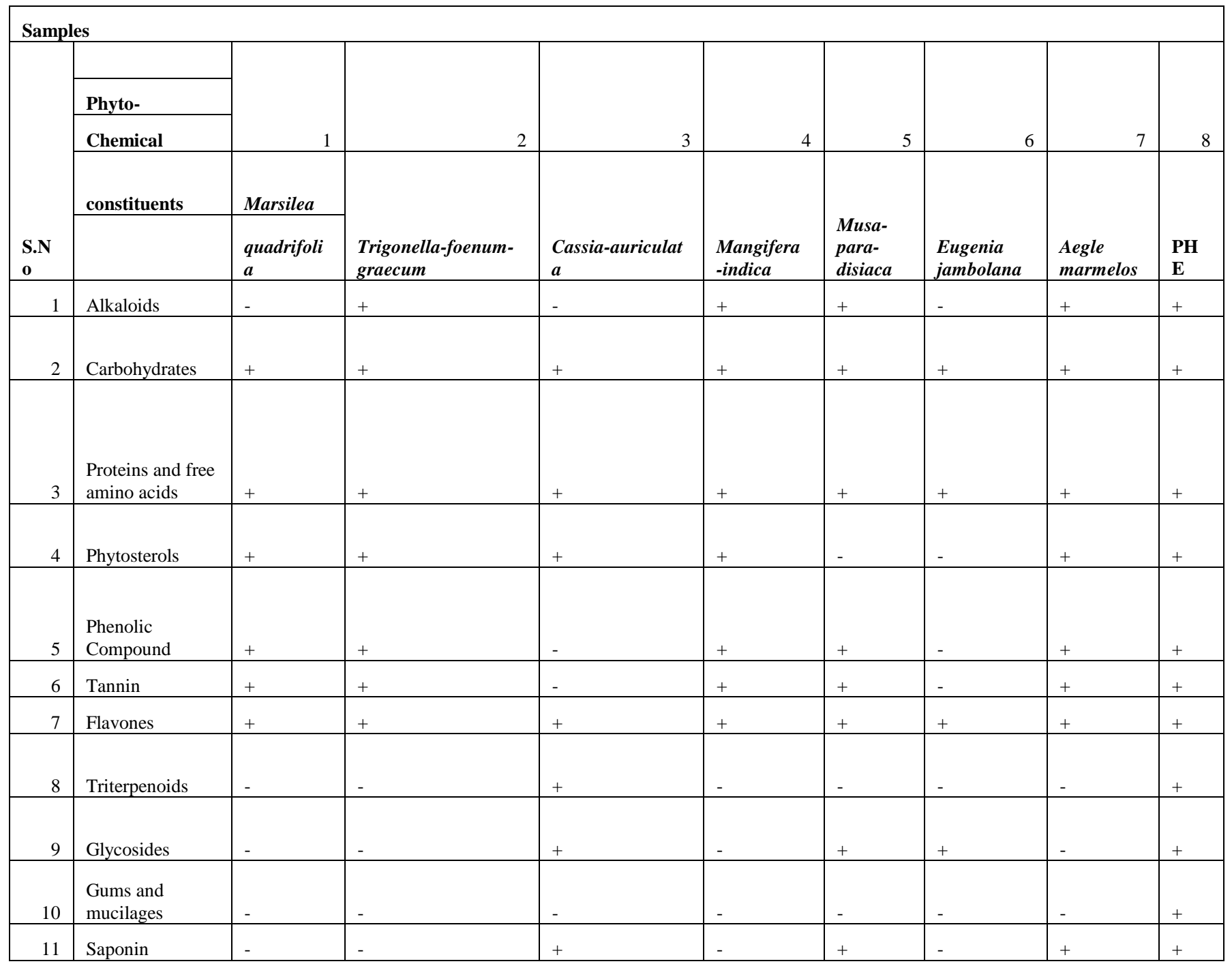

( + ) indicates the presence of Chemical Constituents

( - ) indicates the absence of Chemical Constituents

Table- IV: $\mathbf{R}_{\mathrm{f}}$ Values of TLC solvent systems for different plant extracts

\begin{tabular}{|c|c|c|c|c|c|}
\hline S.No & Name of the plant & Solvent system & $\begin{array}{l}\text { No. of the Spots } \\
\text { detected }\end{array}$ & $\begin{array}{l}\mathbf{R}_{\mathbf{f}} \text { value } \\
\text { calculated }\end{array}$ & $\mathbf{R}_{\mathbf{f}}$ value literature \\
\hline 1 & $\begin{array}{l}\text { Marsilea-quadrifolia } \\
\text { (whole plant) }\end{array}$ & $\begin{array}{l}\text { Hexane : Ethyl acetate : Acetic Acid } \\
(4: 3: 1)\end{array}$ & 3 & $\begin{array}{l}0.36 \\
0.54 \\
0.61\end{array}$ & $\begin{array}{l}\text { Amino acid } \\
\text { Alkaloid } \\
\text { Flavonoid }\end{array}$ \\
\hline 2 & $\begin{array}{l}\text { Trigonella-foenum-graecum } \\
\text { (whole plant) }\end{array}$ & $\begin{array}{l}\text { Chloroform: Ethyl acetate: } \\
\text { Alcohol }(5: 4: 1)\end{array}$ & 2 & $\begin{array}{l}0.29 \\
0.43\end{array}$ & $\begin{array}{l}\text { Amino acid } \\
\text { Flavanoid }\end{array}$ \\
\hline 3 & Cassia-auriculata (Flowers) & $\begin{array}{l}\text { Hexane : Ethyl acetate: Acetic acid } \\
(3: 2: 2)\end{array}$ & 3 & $\begin{array}{l}0.19 \\
0.72 \\
0.89\end{array}$ & $\begin{array}{l}\text { Amino acid } \\
\text { Flavanoid } \\
\text { Terpenoid }\end{array}$ \\
\hline 4 & Mangifera-indica (Leaves) & Hexane : Acetone : Acetic acid (5:3:1) & 3 & $\begin{array}{l}0.26 \\
0.67 \\
0.73\end{array}$ & $\begin{array}{l}\text { Amino acid } \\
\text { Flavanoid } \\
\text { Alkaloid }\end{array}$ \\
\hline 5 & Musa-paradisiaca (Flower) & $\begin{array}{l}\text { Hexane : Ethyl acetate : } \\
\text { Alcohol }(4: 4: 1)\end{array}$ & 2 & $\begin{array}{l}0.34 \\
0.85\end{array}$ & $\begin{array}{l}\text { Amino acid } \\
\text { Flavanoid }\end{array}$ \\
\hline
\end{tabular}


Phytochemical Screening, Spectroscopic Examination and Antimicrobial Evaluation of PHE (Poly Herbal Extract) of Selected Indian Medicinal Herbs

\begin{tabular}{|c|c|c|c|c|c|}
\hline 6 & Eugenia -jambolana (Leaves) & $\begin{array}{l}\text { Chloroform: Alcohol: } \\
\text { Acetic acid }(5: 2: 1)\end{array}$ & 3 & $\begin{array}{l}0.23 \\
0.46 \\
0.79\end{array}$ & $\begin{array}{l}\text { Amino acid } \\
\text { Flavanoid } \\
\text { Alkaloid }\end{array}$ \\
\hline 7 & Aegle-marmelos (Leaves) & Hexane : Acetone : Acetic acid $(5: 3: 1)$ & 3 & $\begin{array}{l}0.34 \\
0.48 \\
0.81\end{array}$ & $\begin{array}{l}\text { Flavanoid } \\
\text { Alkaloid } \\
\text { Phyto-sterol }\end{array}$ \\
\hline 8 & Poly Herbal Extract (PHE) & Hexane : Acetone : Alcohol $(5: 4: 1)$ & 5 & $\begin{array}{l}0.12 \\
0.43 \\
0.56 \\
0.74 \\
0.91\end{array}$ & $\begin{array}{l}\text { Amino acid } \\
\text { Flavanoid } \\
\text { Alkaloid } \\
\text { Saponin } \\
\text { Terpenoid }\end{array}$ \\
\hline
\end{tabular}

\section{CONCLUSION}

The presence of secondary metabolites in Poly-Herbal Extract (PHE) is confirmed by UV-Visible Spectroscopic Studies, Atomic Absorption Studies and Thin layer Chromatography. Alkaloids, carbohydrates, phenols, resins and amino acids and terpenoids in plants may be attributed to their curative antimicrobial properties. Exploitation of the pharmacological properties involve further investigation and identification of these active ingredients by implementing appropriate techniques.

\section{ACKNOWLEDGEMENTS}

The authors sincerely thank the management of Kalasalingam Academy of Research and Education, Tamil Nadu, India for their constant encouragement and support and providing all the necessary facilities for carrying out this research work. The authors are grateful to Arulmighu Kalasalingam College of Pharmacy, Krishnankoil for providing necessary facilities and co-operation during this research work.

\section{REFERENCES}

1. O.K. David and L.W. Emma "Herbal Extracts and Phytochemicals: Plant Secondary Metabolites and the Enhancement of Human Brain Function," Adv Nutr. vol. 2, pp.32-50, 2011.

2. World Health Organization (WHO), "National Policy on Traditional Medicine and Regulation of Herbal Medicines," Geneva: Report of WHO global survey, 2005.

3. G. Angajala, P. Pavan Kumar and R. Subashini, "One-step biofabrication of copper nanoparticles from Aegle marmelos Correa aqueous leaf extract and evaluation of its anti-inflamatory and mosquito larvicidal efficacy," RSC Adv. vol.4, pp.51459-51470, 2014.

4. L.Conboy, T.J. Kaptchuk, D.M. Eisenberg, B. Gottlieb and D. Acevedo-Garcia, "The relationship between social factors and attitudes toward conventional and CAM practitioners," Complement Ther Clin Pract. vol.13, pp.146-157, 2007.

5. B. Schmidt, D.M. Ribnicky, A. Poulev, S. Logendra, W.T. Cefalu and I. Raskin, "A natural history of botanical therapeutics," Metabolism. vol.57, pp.S3-S9, 2008.

6. M. Barrett, "The Hand Book of Clinically Tested Herbal Remedies," 1st edition, CBS Publishers and Distributers, New Delhi. pp.3-6, 2007.

7. G. Angajala and R. Subashini, "Evaluation of larvicidal potential of $\beta$-sitosterol isolated from indigenous Aegle marmelos Correa crude leaf extracts against blood feeding parasites and its binding affinity studies towards sterol carrier protein," Biocatalysis \& Agricultural Biotechnology. vol.16, 586-593, 2018.

8. N. Sahoo, K. Choudhury and P. Manchikanti, "Manufacturing of biodrugs: Need for harmonization in regulatory standards," Biodrugs. vol.23, pp.217-229, 2009.

9. L. Perrin, A. Rakik, S. Yearly, C. Baumbeger, S. Kinloch-de Loies, M. Pechiere and B. Hirschel, "Combined therapy with zidovudine and L-697,661 in primary HIV infection," AIDS. vol.10, pp.1233-1237, 1996.

10. Durr, K.W. Anderson, K.W., C.L. Schneider, J.A. Waterburry, K.K. Bakshi and V.I. Taylor, "Combination Therapy with Zidovudine Prevents Selection of Human Immunodeficiency Virus Type 1 Variants Expressing High-Level,”J Infect Dis. vol.171, pp.1159-1165, 1995.

11. A.D. Kinghorn, D.D. Soejarto, N.P.D. Nanayakkara, C.M. Compadre, H.C. Makapugay, J.M. Hovanec-Brown, P.J. Medon and S.K. Kamath, "A Phytochemical Screening Procedure for Sweet Ent-Kaurene Glycosides in the Genus Stevia,” J. Nat. Prod. vol.47, pp.439-444, 1984.

12. J. Senguttuvan, S. Paulsamy and K. Karthika, "Phytochemical analysis and evaluation of leaf and root parts of the medicinal herb, Hypochaeris radicata L. for in vitro antioxidant activities," Asian Pac J Trop Biomed. vol.4, pp.S359-S367, 2014.

13. L. Long-Ze and M.H. James, "A Screening Method for the Identification of Glycosylated Flavonoids and Other Phenolic Compounds Using a Standard Analytical Approach for All Plant Materials," J Agric Food Chem. vol.55, pp.1084-1096, 2007.

14. C.K. Kokate, "Practical pharmacognosy," 3rd Edition. Vallabh, Prakashan, New Delhi, 1994.

15. G.Y.Yeh, D.M. Eisenberg, T.J. Kaptchuk and R.S. Phillips, "Systematic review of herbs and dietary supplements for glycemic control in diabetes," Diabetes Care. vol.26, pp.1277-1294, 2003.

16. A. Anandan, R. Eswaran, A. Doss, G. Sangeetha and S.P. Anand, Chemical Compounds Investigation of cassia-auriculata Leaves-A potential Folklore Medicinal Plant. Bulletin of Environment," Pharmacology and Life Sciences. vol.1, pp.20-23, 2011.

\section{AUTHORS PROFILE}

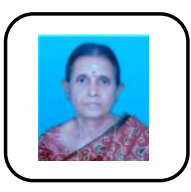

P. Manorama has completed her B. Sc Chemistry from Holy Cross College, Trichy and M. Sc from Avinashi Lingam College, Coimbatore. She has completed M. Phil from Madurai Kamarajar University. Currently she is a research scholar in the Department of chemistry, Kalasalingam Academy of Research and Education. Her research interest is in phytochemistry.

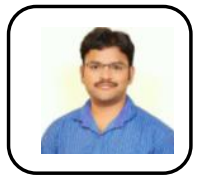

Gangadhara Angajala is working as an Assistant professor in Department of Chemistry at Kalasalingam Academy of Research and Education. He completed his under-graduation in B.Sc with triple major at Government Degree College for Men, Anantapur, Andhra Pradesh and his graduation with specialization in Pharmaceutical Chemistry at Vellore Institute of Technology, Tamil nadu. He obtained his Ph.D with specialization in Organic and Medicinal Chemistry from VIT University. His research area includes synthesis of new quinoline scaffolds with hypoglycemic efficacy by using nanocatalysis.

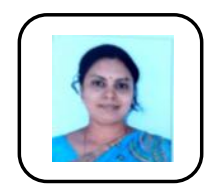

D.Geetha has completed M. Sc in Chemistry discipline from Bharathidasan University, M. Phil., from Annamalai University. She completed Ph. D from Jaypee University in 2016. She is currently working as an Assistan professor at Kalasalingam Academy of Research and Education from 2017 onwards. Her field

of interest is bio surfactant. She has published 7 papers in reputed international journals. 